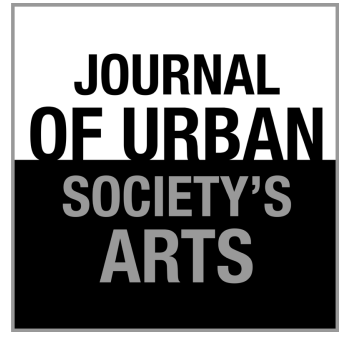

Volume 1 Nomor 1, April 2014: 27-43

\title{
Instrumen Musik Barat dan Gamelan Jawa dalam Iringan Tari Keraton Yogyakarta
}

\author{
R.M. Surtihadi
}

Jurusan Musik, Fakultas Seni Pertunjukan, Institut Seni Indonesia Yogyakarta

Jln. Parangtritis km 6,5 Sewon, Bantul, Yogyakarta 55001

Tlp.08156883788,E-mail: surtihadi@isi.ac.id

\begin{abstract}
ABSTRAK
Perpaduan instrumen musik Barat dengan instrumen gamelan Jawa untuk mengiringi tari di Keraton Yogyakarta sudah berlangsung sejak lampau. Hingga saat ini perpaduan tersebut masih dapat dijumpai. Bermula dari peristiwa kontak budaya Barat dan Timur, instrumen musik Barat telah menjadi bagian dari kelengkapan upacara protokoler Keraton Yogyakarta. Tujuan penulisan ini untuk membuat kajian historis perpaduan gamelan Jawa dengan seperangkat instrumen musik orkestra Barat untuk mengiringi pertunjukan tari putri pada bagian kapang-kapang Bedhaya, Srimpi, dan tari putra Lawung Ageng Keraton Yogyakarta. Beberapa instrumen musik Barat seperti instrumen genderang, tambur (percussion section), instrumen gesek (string sections), instrumen tiup kayu (woodwind sections) dan tiup logam (brass sections) digunakan dalam mengiringi tarian-tarian tersebut di atas. Metode kualitatif analisis data dipakai untuk mengupas masalah ini. Namun, pendekatan sosial-politik juga akan dipakai dalam mengulas permasalahan yang terkait. Berdasarkan penelitian ini dapat disimpulkan bahwa dampak peristiwa intrik politik yang terjadi di keraton terbukti telah memengaruhi kehidupan keseniannya. Kebutuhan upacara protokoler yang merupakan kegiatan rutin pada saat itu dilengkapi dengan berbagai macam sajian pertunjukan musik untuk menambah hidup suasana pesta dansa dengan diiringi musik berirama waltz.
\end{abstract}

Kata kunci: instrumen musik Barat, iringan tari keraton, upacara protokoler

\begin{abstract}
Blend of Western Musical Instruments and Javanese Gamelan in Dance Accompaniment and Protocol Ceremonies of Keraton Yogyakarta. Western musical intruments have been combined with the Javanese gamelan instruments to accompany dances performed in Keraton Yogyakarta (the Yogyakarta Palace). It started with the coming of the Western culture which then 'interacting' with the East. Since then, the Western musical instruments have completed the protocol ceremonies held by Keraton Yogyakarta. The objective to be obtained with this research is to historically study the blend of the Javanese gamelan with the Western orchestra musical instruments in accompanying the female dance performances, which are the kapang-kapang part of Bedhaya and Srimpi, and the male one i.e. Lawung Ageng. Some Western musical instruments like, drums (percussion sections), strings instruments (string sections), woodwind instruments (woodwind sections) and brass (brass sections) are used in those dances shows. The data are analyzed utilizing the qualitative method. The problem will also be approached socio-politically. It can be concluded that the political intrigue in the palace has brought about some impacts on the art living in it. Waltz dance is performed to enliven the dance parties and complements the protocol ceremonies as the routine events.
\end{abstract}

Keywords: Western musical instruments, royal dance accompaniment, protocol ceremony 


\section{Pendahuluan}

Kehadiran musik Barat (Eropa) di istana-istana di daerah Jawa Tengah (Surakarta dan Yogyakarta) diawali dari musik militer. Kongsi Dagang Belanda atau VOC (Vereenidge Oost-indische Compagnie) adalah pihak yang pertama kali memperkenalkan musik tersebut. Seorang pedagang Perancis bernama Jean-Baptise Tavernier menceritakan adanya iringan dua instrumen terompet yang menyertai dirinya dengan Gubernur Jendral Van Der Lijn saat bertamasya ke Batavia pada tahun 1648; asumsinya adalah, musik militer Eropa berada di Jawa sejak pertengahan abad ke-17 (Sumarsam, 2003:95).

Penelitian tentang perpaduan instrumen musik Barat dan gamelan Jawa untuk iringan tari ini pernah dilakukan oleh penulis tahun 1995, dengan judul "Instrumen Musik Tradisi Barat dalam Iringan Tari dan Upacara Protokoler Keraton Yogyakarta (Sebuah Tinjauan Historis)" dalam bentuk skripsi. Penulisan artikel ini dimaksudkan untuk melengkapi dan menyempurnakan penelitian tersebut karena pada waktu penulis melakukan penelitian tersebut mengalami keterbatasan sumber data dan referensi-referensi kepustakaan yang kurang mendukung. Setelah penulis meninjau ulang tentang penelitian tersebut, melalui penulisan artikel ini penulis bermaksud untuk mengoreksi ataupun menambah kekurangan informasi data yang diambil dari sumber primer, baik berupa arsip-arsip milik Keraton Yogyakarta maupun hasil-hasil penelitian yang terkait tentang peristiwa budaya di Keraton Yogyakarta pada masa lampau.

Keraton Yogyakarta sebagai pusat budaya Jawa mempunyai fakta sejarah yang penting sebagai centre of exellence mempunyai ciri khas sebuah istana kerajaan. Berbagai aktivitas seni budaya sejak masa lampau hingga sekarang telah mengalami perkembangan. Namun, perkembangan yang terjadi karena faktor budaya lokal yang berinteraksi dengan budaya asing. Bidang seni khususnya musik Barat bermula dari musik militer. Musik militer di Keraton Yogyakarta muncul sejak masa pemerintahan Sultan Hamengku Buwana I (1755-1792), sebagaimana dikemukakan oleh Ricklefs (1974: 87) tentang sumbangan instrumen musik Barat berupa instrumen terompet dari pemerintah $\mathrm{Be}$ - landa kepada Keraton Yogyakarta.

Menurut catatan Groneman, pada akhir abad ke-19 Korps Musik Prajurit Keraton Yogyakarta terdiri dari tiga macam ensambel, (1) Korps Musik yang memainkan campuran instrumen Jawa dan Eropa, (2) Korps Musik yang memainkan instrumen musik Eropa, (3) Korps musik yang memainkan instrumen Jawa saja. Sebagai contoh, beberapa kelompok Korps Musik Prajurit memainkan dua drum Eropa dan satu seruling, sedangkan kelompok lain terdiri dari pemain terompet metal Eropa, drum Eropa dan seruling, dimainkan bersama-sama dengan instrumen Jawa, yakni gong dan bendhé, kècèr (cymbal kecil), dan kendhang ketipung. Groneman juga menyebutkan bahwa semua pemain musik itu adalah prajurit-musikus Jawa (abdi Dalem Prajurit-Musikan) yang memakai seragam ala militer Eropa abad ke-19 (Sumarsam, 2003: 96).

Salah satu "bregada" Prajurit Keraton Yogyakarta, yakni Prajurit Jagakarya mempunyai lagu kebesaran yang disebut dengan "Mars Pandebruk", sebuah mars dengan sukat 4/4. Mars tersebut dimainkan dengan instrumen seruling, slomprèt, dan bendhé (Kunst, 1973: 294). Nama yang unik tersebut adalah pelafalan Jawa dari kata "Mars Van den Broek", yang kemungkinan besar diambil dari nama komandan militer Belanda. Dalam perkembangannya, karena faktor sosialpolitik yang terjadi di keraton-keraton Jawa Tengah (Surakarta dan Yogyakarta), aktivitas bermusik Barat pun semakin sering terjadi.

Dari beberapa sumber yang telah penulis telusuri, seorang Sultan Yogyakarta pernah mendapat hadiah berupa pemberian instrumen musik dari seorang Sultan Turki-Ottoman, namun instrumen tersebut tidak dijelaskan jenisnya berupa instrumen musik Barat atau instrumen musik dari Turki (Tim Peneliti Akademi Musik Indonesia, 1982: 3). Arsip Keraton Yogyakarta yang disita bala tentara Inggris sewaktu mereka menduduki Keraton Yogyakarta (1812) memberikan data yang menarik. Pertama, pada perayaan Grèbèg Siyam tahun 1807 di bawah pemerintahan Sultan Hamengku Buwana II (17921810), di antara benda-benda yang diarak dalam perayaan tersebut adalah dua buah tambur. Dalam Korps Musik Keprajuritan yang terdiri dari sepuluh 
bregada, masing-masing mempunyai satu tambur atau lebih. Adapun total instrumen berjumlah lima puluh lima tambur, ditambah tiga puluh sembilan seruling. Kedua, pada tahun 1805 sudah dikenal jabatan abdi-dalemtambur suling salompret (Carey, 2000: 284).

Babad Ngayugyakarta volume III memberikan informasi penting bagi kajian historis penulisan ini. Babad Ngayugyakarta sebagaimana sebuah catatan harian seorang sultan yang sedang bertahta, memuat aktivitas sultan dan hasil karyakarya yang telah dilakukan selama memerintah. Informasi yang didapat dari sumber ini adalah tentang peristiwa-peristiwa kontak budaya yang diawali dari upacara protokoler hingga aktivitas seni budaya.

Sumber lain tentang keberadaan instrumen musik Barat adalah pada salah satu dokumen arsip Keraton Yogyakarta berjudul Ngayugyakarta Pagelaran, tulisan Rng. Kartahasmara transliterasi Wibatsu Harianto Soembogo (Mahadewa, 1990). Tulisan ini memberikan informasi tentang data Yasan Dalem dari Sultan Hamengku Buwana (HB) I sampai Sultan HB VIII. Informasi khusus dari dokumen ini adalah penggunaan instrumen musik Barat dipadukan dengan gamelan Jawa untuk mengiringi tari terdapat dalam data Yasan Dalem Sultan HB V (1923-1955) dan Sultan HB VIII (1921-1939).

Perpaduan instrumen musik Barat dengan gamelan Jawa yang dilakukan oleh para musisi Keraton Yogyakarta dan dibantu oleh musisi asing adalah suatu usaha untuk menciptakan komposisi gamelan yang dinamakan gendhing mares/ mars (Sumarsam, 2003: 113). Penciptaan dan penggunaan gendhing mares tersebut menurut musikolog Jaap Kunst disebut sebagai "typically hybrid ensembles" (tipikal ensambel yang bersifat hybrid atau "blasteran" (Kunst, 1973: 293-294).

Perpaduan instrumen musik Barat dengan gamelan Jawa untuk iringan tari putri terlihat pada Bedhaya dan Srimpi pada bagian kapang-kapang dalam iringan gendhing mars. Demikian pula dalam iringan beksan Lawung Ageng yang dibawakan oleh sejumlah penari putra, hampir seluruh repertoar diiringi dengan gamelan Jawa bersamaan (unisono) dengan instrumen musik Barat seperti trombon, terompet, klarinet, genderang dan tambur, kecuali pada gerakan perang (sodoran). Pada mulanya, beksan Lawung ini diiringi oleh separangkat gamelan khusus berlaras pelog yang merupakan gamelan pusaka Keraton Yogyakarta bernama Kandjèng Kyai Guntursari (Mardowo, 1981: 130). Walaupun bunyi yang dihasilkan dari perpaduan instrumen gamelan dengan instrumen musik Barat terdengar agak janggal bagi telinga musisi Barat, tradisi yang telah mengendap di keraton ini terkesan sangat anggun dan agung bagi telinga Jawa (Soedarsono, 2010: 62).

Berdasarkan paparan tersebut, pokok bahasan dalam tulisan ini akan dibatasi dalam kajian historis peristiwa musikal yang terjadi di Keraton Yogyakarta yang melibatkan instrumen musik Barat baik itu sebagai iringan tari maupun dalam upacaraupacara seremonial dan protokoler masa pemerintahan Sultan Hamengku Buwana V (1823-1855) dan Sultan Hamengku Buwana VIII (1921-1939).

\section{Pembahasan}

Dalam pembahasan ini pendekatan sosialpolitik akan dibatasi pada kedudukan politis sultan sebagai pemegang otoritas. Dengan demikian, secara sosial peranan itu telah melekat dalam keputusan-keputusan yang bersifat politis. Sudah barang tentu konsepsi kekuasaan pemegang otoritas akan memengaruhi konsep-konsep kehidupan lainnya termasuk konsep keseniannya. Berbicara tentang sultan sebagai pemegang otoritas, faktor kunci yang telah dikemukakan oleh Max Weber sangat relevan diungkapkan. Dikatakan bahwa tiga jenis otoritas sangat dipenuhi oleh pribadi sultan yakni: (1) otoritas karismatis, dimiliki berdasarkan pengaruh dan kewibawaan pribadi; (2) otoritas tradisional, dimiliki berdasarkan pewarisan atau turun-temurun; (3) otoritas legal rasional, yaitu dimiliki berdasarkan jabatan serta kemampuannya (Kartodirdjo, 1993: 150). Pencermatan yang merajuk pada fungsi upacara terhadap penggunaan instrumen musik Barat ataupun gamelan Jawa dapat ditelusuri dari peristiwa-peristiwa yang terjadi di Keraton Yogyakarta baik sebagai iringan tari maupun pengiring upacara-upacara protokoler dan seremonial. 


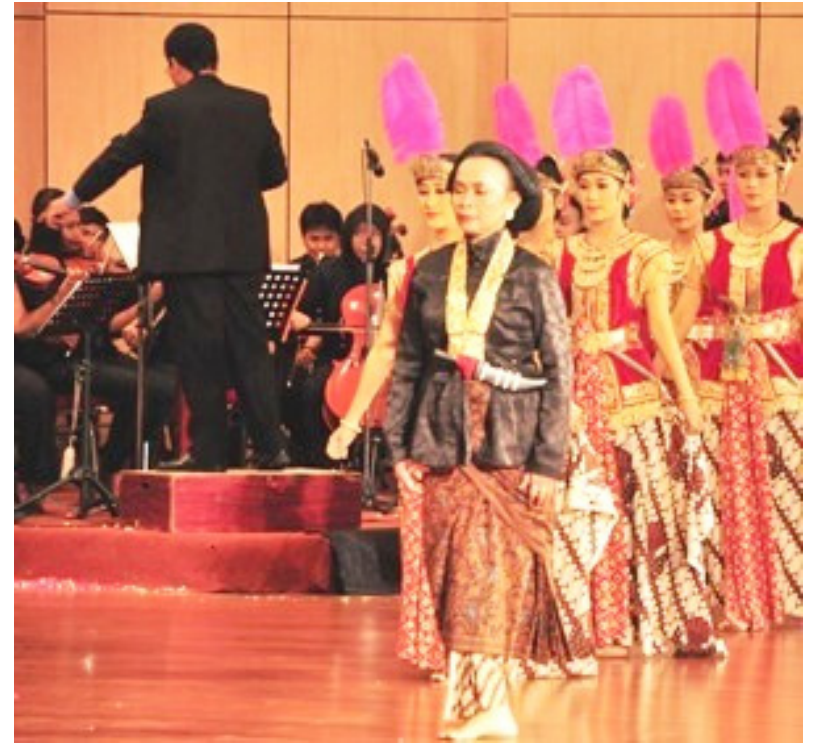

Gambar 1. Bedaya Sang Amurwabumi diiringi dengan perpaduan instrumen Orkestra Barat dengan gamelan Jawa. Foto diambil saat penganugerahan Doktor Honoris Causa bidang Seni Pertunjukan bagi Sultan Hamengku Buwana X dalam Sidang Senat Terbuka ISI Yogyakarta tanggal 27 Desember 2011 di Concert Hall ISI Yogyakarta.

(Sumber: dokumentasi Kardi Laksono)

\section{Periode Pemerintahan Sultan Hamengku Buwana V (1823-1855)}

Seperti apa yang telah diuraikan dalam Pendahuluan, periode pemerintahan Sultan Hamengku Buwana V (1923-1955) terjadi kontak budaya asing yang mengendap ke dalam budaya Jawa (keraton) dengan adanya perpaduan instrumen musik Barat ke dalam musik iringan tari Jawa ataupun upacara protokoler. Jika pernyataan tersebut merupakan sebuah indikasi periode historis, sumber-sumber yang dapat diacu sebagai peristiwa kontak budaya itu lebih merupakan sifat hubungan yang terbatas dalam upacara protokoler dan dalam bidang seni (Surtihadi, 1995: 54). Hal ini dikarenakan satu alasan bahwa, pernyataan tersebut telah dijelaskan dalam Babad Ngayngyakarta tentang peristiwaperistiwa kontak budaya yang diawali dari upacara protokoler hingga berpengaruh dalam bidang seni. Berikut ini kutipan dari Babad Ngayugyakarta yang menggambarkan upacara pemberian penghargaan Bintang Komandur kepada Sultan Hamengku Buwana V dari Pemerintah Hindia Belanda yang disampaikan oleh Tuan Residen Komisaris, kemudian dilanjutkan dengan pesta perjamuan makan dan minum di keraton dengan diselingi pertunjukan tari bedhaya, srimpi, dan tarian dansa:
54. Neng Mandungan kinurmat salompret tambur, Sarawuhnja Sri Penganti, kinurmat salompret tambur, lumestari mandjing puri, salompret musikan nyentor.

55. Barung lawan merdongga serakit umyung, jata kang aneng Sitinggil, duk gongsa munggang wus suwuk, Dyan Patih lan wong rèh djawi, wangsul magelaran ngrandon.

56. Tan antara Djeng Residen kondur, sakbangsanireng kumpeni, kinurmat umyung gumuruh, wus bubar sagung kang nangkil, mangkana kang winirahos.

57. Karsa Dalem ngurmati bintang Komandur, akasukan neng djro puri, lan Tuwan Residen iku, sakbangsanira kumpeni, atenapi para Mitra.

58. Pra Pangeran dyan Patih sakondangipun, mawanti bedhajan srimpi, dedangsahan nginum-inum, dhahar pista lan kundisi, trusta manahing gunging wong.

59. Wektu iku kang sareng antuk komandur, Djeng Sunan Surakarta-di, kang antuk Riddr ing Ordu, Djeng Pangeran Mangkunegari, lan Djeng Paku Alam manggon.

(Babad Ngayugyakarta Vol. III. SB. Ms. Canto: 54-59, 73: Megatruh, p. 442).

Terjemahannya sebagai berikut:

54. Di Mandungan dihormati trompet dan tambur, sesampainya di Sri Manganti, dihormati terompet dan tambur, terus masuk ke keraton, terompet para musisi berbunyi.

55. Bersamaan dengan dua perangkat gamelan berbunyi, yang berada di Sitinggil, ketika gamelan munggang berhenti, Patih dan pegawai urusan luar, kembali ke Pagelaran lagi.

56. Tidak lama Residen pulang, dan para kumpeni lainnya, dihormati dengan ramai, setelah semua selesai menghadap, demikianlah yang diceritakan. 
57. Sultan bermaksud menghormati Bintang Komandur, dengan bersenang-senang di dalam keraton, dengan Tuan Residen itu, bersama-sama bangsa kumpeni, demikian pula para sahabat.

58. Para Pangeran dan Patih serta para tamu, menantikan tari bedhaya dan srimpi, sambil minum-minum dan dansa, pesta perjamuan makan dan bersulang, yang membuat hati semua orang senang,

59. Pada waktu itu yang mendapat bintang komendur,

Sri Susuhunan di Surakarta, yang menerima Riddr ing Ordu, Kangjeng Pangera Mangkunegara, dan Kangjeng Paku Alam.

Dari uraian tersebut dapat diketahui bahwa pemberian penghargaan bintang Komandur tidak hanya diberikan kepada Sultan Hamengku Buwana V, namun juga diberikan kepada Sri Susuhunan Surakarta, Pangeran Mangkunegara, dan Kangjeng Paku Alam. Terkait dengan permasalahan ini akan diuraikan beberapa kutipan dari Babad Ngayugyakarta Volume III yang mengacu pada peristiwa upacara protokoler ataupun peristiwa seni budaya sebagai berikut:

52. Saurutirèng prajurit, tumekèng Prawiratama, ingkang sinambung wurine, musikan gya upatjara, myang antero bayongan, tumuli jempana Agung, tithane Djeng Dayinta.

53. Prajurit Nyutra angapit, ing wuri Paneran werdah, Mantri-muka sakantjane, ingkang ngurung-urung lampah, djadjaran wahos benang, lan macanan selanipun, sineling bendera cina.

54. Sakmarga prayitneng westi, subamanggala gumentar, salomprét tambur lan bèndhé, musikan angantak-antak, muryani kapirenan, panjere urut lurung, umbul-umbul pajeng krenda.
(Babad Ngayugyakarta Vol. III. SB. Ms. Canto: 52-54, Asmarandana: 73, pp. 381-'82).

Terjemahannya sebagai berikut:

52. Urut-urutan barisan prajurit, dari prajurit Prawiratama, yang disambung di belakangnya, musisi sebagai pengiring upacara, dan segala perlengkapan upacara, kemudian tandu Agung, kendaraan permaisuri sultan.

53. Prajurit Nyutra mengapit, di belakang pangeran sepuh, Patih dan bawahannya, yang menyertai perjalananan, prajurit Jajar sebagai penunjuk jalan, dan macanan diseling, yang membawa bendera Cina.

54. Di perjalanan selalu waspada, Komandan memberi aba-aba, terompet, genderang dan bèndhé, yang dimainkan para musisi, mulai terdengar suaranya, suaranya sampai ke setiap sudut jalan, umbul-umbul sebagai tanda.

Uraian tersebut menggambarkan peristiwa adanya upacara protokoler yang melibatkan instrumen musik Barat (terompet dan genderang) sebagai kelengkapan upacara penghormatan. Mencermati struktur upacara yang tertulis dalam babad tersebut, sangat dimungkinkan bahwa deskripsi tersebut mengacu pada prosesi upacara kirab perkawinan Sultan Hamengku Buwana V. Mengenai prosesi seperti ini telah diketahui sebagai acuan resmi hingga masa pemerintahan Sultan Hamengku Buwana VIII (1921-1939) (Soedarsono, 1989: 162 163). Keterlibatan para musisi yang memainkan instrumen terompet dan genderang mempunyai asumsi bahwa instrumen-instrumen musik tersebut merupakan peninggalan dari Sultan Hamengku Buwana I yang pernah menerima sejumlah instrumen terompet dari Pemerintah Hindia Belanda, seperti yang dikemukakan oleh Ricklefs (1974: 87) sebagai berikut:

Slowly the Sultan's authority over his court and people, many of whom had so recently renounced the undisciplined life of rebellion, was established. A number of rebels submitted 
to him and were accepted as his subject. The form of kingship were augmented by aquiring pusakas and by elaborating the Sultan's visible status. In the latter he was assisted by Dutch provision of trumpeters, elephants, Persian horses, and a coach. The Dutch commented on Mangkubumi's concern in all these things to follow the example of the previous rulers of the Mataram empire'.

(Lambat laun kekuasaan Sultan atas istana dan rakyatnya sudah mapan/tertata baik, karena banyak dari mereka telah meninggalkan kehidupan yang tidak teratur. Sejumlah yang memberontak kepadanya telah menerima kenyataan sebagai suatu subyeknya. Bentuk-bentuk martabat raja menjadi besar dengan memperoleh dan meningkatkan status Sultan yang nampak. Pada akhirnya ia menerima bantuan dari Belanda berupa sejumlah pemain terompet, gajah-gajah, kuda-kuda dari Persia dan sebuah kereta. Belanda memuji Pangeran Mangkubumi dalam segala hal yang mengikuti contoh kekuasaan pemerintahan Kerajaan Mataram sebelumnya.)

Dari kutipan tersebut dapat diketahui bahwa pemerintah Belanda terlibat dalam melengkapi status lahirnya Keraton Kasultanan Yogyakarta dengan memberikan sejumlah pemain terompet, gajahgajah, kuda-kuda dari Persia, dan sebuah kereta. Bentuk peristiwa lain yang menggambarkan kontak budaya Barat dan budaya lokal terdapat dalam upacara kunjungan Sultan Hamengku Buwana V ke loji (Upacara Tedhak Lodji).

Berikut ini kutipan dari Babad Ngayogyakarta yang menggambarkan upacara saling berkunjung antara Sultan Hamengku Buwana V ke loji (tedhak lodji), tempat Tuan Residen tinggal. Sebaliknya, Tuan Residen juga berkunjung ke keraton dengan upacara penghormatan protokoler dilanjutkan dengan pertunjukan tari dan musik dansa-dansi:

50. Wong kumpeni seketar kang baris,

drël sandjata angrok,

barung tambur lan musikane, mawurahan gumentar nengkeri,

jata Sri Bupati,

miwah Djendral Agung.
51. Wusnja mandjing dalem residensi, anulja Sang Katong, budhal kondur ingater Residen, mungging rata Njai Djimat nguni, sapraptaning puri,

Djeng Residen wangsul.

(Babad Ngayugyakarta Vol. III. SB. Ms. Canto: 50-51, Midjil : 65, p. 390).

Terjemahannya sebagai berikut:

50. Orang kumpeni yang sedang berbaris, membunyikan tembakan salvo, bersamaan dengan para musisi membunyikan genderang, bersahut-sahutan menandai, datangnya para Bupati, dan Jendral Agung.

51. Sesudah masuk ke rumah residen, Sri Baginda lalu, berangkat pulang diantar Residen, sampai di kereta Nyai Djimat, setibanya di keraton, Tuan Residen kembali.

Berdasarkan kutipan di depan, peristiwa tersebut menggambarkan upacara kunjungan Sultan Hamengku Buwana V ke rumah Tuan Residen (Tedhak Lodji) dengan mengendarai kereta Nyai Djimat. Upacara penyambutan secara militer dengan tembakan salvo yang bersamaan dengan bunyi genderang bersahut-sahutan sangat dimungkinkan bahwa upacara kunjungan kedua tokoh ini dilakukan secara bergantian. Dalam acara saling berkunjung tersebut diadakan pesta perjamuan dan minum anggur diselingi pertunjukan musik, tari dan dansa (Surtihadi, 1995: 63).

Babad Ngayngyakarta Volume III memberi informasi penting dalam peristiwa upacara protokoler sehubungan dengan pesta perjamuan baik di keraton maupun di rumah Residen sebagai berikut:

9. Kendelnja musikan hurmat, wedang madju kopi pohan myang hertih, werata njamikanipun, binarung lan musikan, duk antara luwaring sewaka ladju, main dansah lan kasukan, larih mider wanti-wanti.

10. Musikanira gumentar, amurjani sadjaknja salin-salin, antaranja wus nutug, pahargyan dhahar pista, 
sinelan myang kundisi nginum anggur,

ping sapta binarung surak, musikanira nimbangi.

(Babad Ngayogyakarta Vol. III., SB. Ms. Canto: 9-10, Pangkur: 66, p.397).

Terjemahannya sebagai berikut:

9. Setelah para musisi berhenti menghormat, minuman kopi, susu, dan teh, beserta kudapan sudah merata, bersamaan dengan iringan musik, ketika sudah selsesai perjamuan diteruskan dengan, menari dansa, dan suka ria, minuman disajikan terus-menerus.

10. Musiknya terdengar membahana, menghiasi suasana silih berganti, dirasa sudah cukup, perjamuan pesta makan, diselingi bersulang dan minum anggur, tujuh kali disertai sorak-sorai, diiringi alunan musik

Kutipan tersebut menjelaskan bahwa upacara saling berkunjung merupakan sebuah pesta perjamuan makan dan minum antara Sultan dengan Tuan Residen, para bangsawan serta pembesar Belanda. Penggunaan instrumen musik Barat dalam pesta perjamuan dimaksudkan untuk menghidupkan suasana pesta. Jika menyimak fungsi dan peran instrumen musik Barat yang tertuang dalam syair babad tersebut, instrumen musik Barat mempunyai beberapa fungsi, yakni untuk penghormatan, untuk musik selingan makan dan minum anggur, bahkan untuk mengiringi tarian dansa.

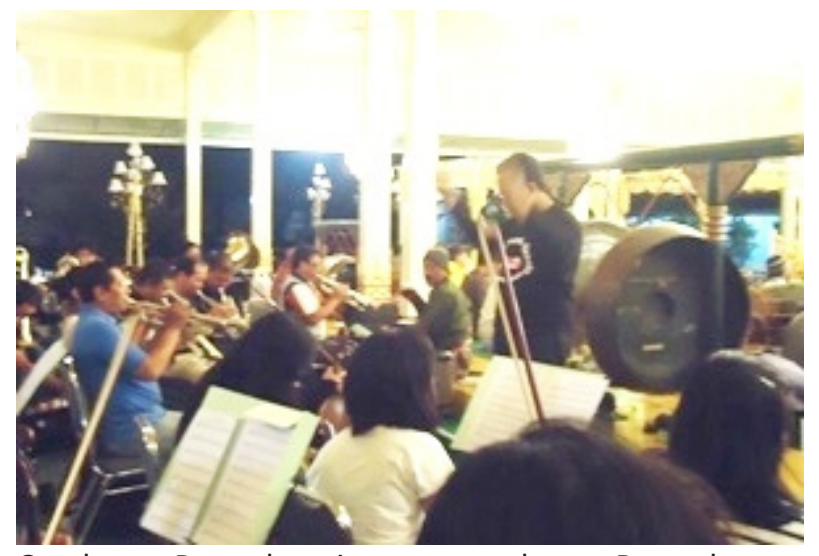

Gambar 2. Perpaduan instrumen orkestra Barat dengan gamelan Jawa untuk mengiringi Tari Bedaya Wiwaha Sangaskara dalam sebuah latihan di Bangsal Kepatihan (Sumber: dokumentasi R.M. Surtihadi)
Penelusuran terhadap prosesi upacara protokoler yang melibatkan instrumen musik Barat sebagai tanda penghormatan ataupun sebagai musik selingan sebuah pesta perjamuan makan dan minum kemudian sajian pertunjukan beksan Bedhaya, Srimpi, dan tarian dansa yang diiringi dengan musik Barat tampak jelas digambarkan dalam teks Babad Ngayogyakarta berikut.

Canto: 3-6, 67: Dhandhanggula:

3. Musik barung merdèng ngurmati, para Ratu wus lenggah ing Bangsal, Kentjana sami tur tabe, kelawan Djendral Agung, tata lenggah ing Bangsal Rukmi, Sang Nata aneng kiwa, dene kang sumambung, bangsa kumpeni sedaya, tengen Djendral pra njonjah lan pra putri, tuwin para pangeran.

4. Dene Raden Danuredja Patih, sakondangja sumiwi neng tratag, gya dhahar wedang sumahos, lawan njamikanipun, kang ngladeni para bupati, dupi sampun werata, gya lelangen madju, Srimpi miwah Bedhaya, nuli dansah larik mider wanti-wanti, Sang Nata lawan Djendral.

5. Akasukan aneng Gedhong Kuning, Tuwan Djendral resep tyas katjarjan, lumyat rakiting kedhaton, gya dhahar pista kembul, myang kundisi mawanti, luwaring dhahar pista, Djendral ladjeng kondur, kekanthën lawan Sang Nata, kandhèg aneng pregolan Sri Penganti, sawusnja tetabejan.

6. Tuwan Djendral kondur marang Lodji, nitih rata sakmarga kinurmat, Sang Nata lan Djeng Residen, kanthën asta ngedhaton, tan antara Tuwan Residen, kondur mring lodji bubar, jata Djendral Agung, lami dennja neng Ngajogja, apepriksa ing rèh lelangen Narpati, dupi sampun palasta. 
Terjemahannya sebagai berikut:

3. Musik berbunyi bersama gamelan menghormati, para pembesar keraton telah duduk di Bangsal Kencana, saling bersalaman, Jendral Agung duduk di Bangsal Kencana, Sri Baginda di sebelah kiri, dan yang berada di belakang, bangsa kompeni semua, di sebelah kanan Jendral para wanita, wanita Belanda dan para putri, beserta para pangeran.

4. Adapun Patih Danureja, dan lainnya siaga di teras, kemudian makan dan minum disajikan, beserta makanan kecil (kudapan), yang melayani para bupati, setelah merata, pertunjukan dimulai, Srimpi serta Bedhaya, Kemudian dansa dan minuman disajikan terus-menerus, Sri Baginda dengan Jendral.

5. Bersenang-senang di Gedhong Kuning, Tuan Jendral senang hatinya, Terhadap bangunan-bangunan keraton, segera makan bersama, dan bersulang berkali-kali, setelah selesai pesta makan, Jendral lalu pulang, bergandengan tangan dengan Sultan, berhenti di pintu gerbang Sri Manganti, setelah saling bersalaman.

6. Tuan Jendral pulang ke Loji, naik kereta di jalan dihormati, Sri Baginda dan Tuan Residen, bergandengan tangan ke keraton, tidak berapa lama Tuan Residen, pulang ke Loji selesai, demikian pula Jendral Agung, lama berada di Yogyakarta, melihat kesenian keraton, hingga sampai selesai.

Pernyataan dari kutipan Babad Ngayogyakarta tersebut dapat menjadi indikasi penggunaan instrumen musik Barat dalam upacara protokoler di Keraton Kasultanan Yogyakarta. Namun, sangat dimungkinkan bahwa penggunaan instrumen musik
Barat dalam iringan tari Bedhaya dan Srimpi juga berawal dari peristiwa tersebut.

Salah satu data Yasan Dalem yang menarik untuk dikemukakan dalam tulisan ini adalah data Yasan Dalem dari periode pemerintahan Sultan Hamengku Buwana V (1823-1855) tentang perpaduan antara instrumen gamelan keraton ( $k$ agungan Dalem gangsa), dengan instrumen musik Barat berupa terompet, dan genderang untuk mengiringi beberapa tarian (beksan) bagian kapang-kapang Bedhaya dan Srimpi, serta iringan beksan Trunajaya. Dari sumber ini diperoleh keterangan bahwa yang mengerjakan perpaduan kedua jenis instrumen tersebut adalah dua orang Belanda yang bernama Van Gought dan Smith atas perintah (Dhawuh Dalem) Sultan Hamengku Buwana V (Kartahasmara, 1990: 191).

Berikut kutipan dari Ngayogyakarta Pegelaran yang menjelaskan hal tersebut:

9. Murjani Yasa Gendhing-gendhing sabrangan kanthi kairing ungeling musik trompet, tambur, bedhug lan sasaminipun. Kagem nggangsani Kapang-kapang majenging/ munduripun Lelangen Dalem Bedhaya, Sarta Beksan Trunajaya. Ingkang nindakaken nggarap jumbuhing gangsa lawan musik tiyang Walandi inggih Van Gough sarta Smith. (Kartahasmara, 1989: 191).

(Mulai membuat gendhing-gendhing sabrangan dengan diiringi suara musik terompet, genderang, bedhug, dan sejenisnya. Untuk mengiringi Kapang-kapang maju/mundurnya Lelangen Dalem Bedhaya, serta Beksan Trunajaya. Yang disuruh mengerjakan perpaduan gamelan dengan musik orang Belanda yaitu Van Gough serta Smith).

Dalam sumber teks tersebut dapat dikaitkan dengan kedudukan seorang Sultan sebagai pemegang otoritas, asumsinya adalah bahwa konsepsi kekuasaan pemegang otoritas akan memengaruhi konsep-konsep kehidupan yang lain termasuk dalam konsep keseniannya. Dengan demikian dapat dinyatakan bahwa beberapa terminologi bahasa seperti Karsa Dalem, Dhawuh Dalem, Yasan Dalem, Lelangen Dalem, dan sebagainya, menjadi sah bila dikaitkan dengan konsepsi kekuasaan Sul- 
tan, dan kaitannya dengan konsepsi seni (Soedarsono, 1989: 1-5).

\section{Periode Pemerintahan Sultan Hamengku Buwana VIII (1921-1939)}

Pengamatan terhadap periode historis seni pertunjukan di Keraton Yogyakarta menjadi lebih menarik pada masa pemerintahan Sultan Hamengku Buwana VIII (1921-1939). Pada masa itu budaya Barat semakin tampak dalam memengaruhi konsepsi seni di Keraton Yogyakarta. Ngayugyakarta Pagelaran menggambarkan secara lebih jelas kedudukan pengaruh itu dalam data Yasan Dalem periode Sultan Hamengku Buwana VIII (19211939) sebagai berikut:

7. Karsa Dalem njangkepi iringaning Kapangkapang Bedhaya/Srimpi, Beksan Trunajaya, Srimpi Pandelori miwah Srimpi Muncar, kanthi tambahan musik gesek/biola. (Kartahasmara, 1990:193).

(Karsa Dalem melengkapi iringan Kapangkapang Bedhaya/Srimpi, beksan Trunajaya, serta Srimpi Pandelori dan Srimpi Muncar, dengan tambahan instrumen musik gesek/ biola).

Dalam kutipan yang diambil dari Ngayugyakarta Pagelaran tersebut, sangat jelas bahwa penambahan instrumen gesek/biola dalam iringan tari tersebut atas keinginan Sultan Hamengku Buwana VIII. Diketahui bahwa pada masa Pemerintahan Sultan Hamengku Buwana VIII (1921-1939), Keraton Yogyakarta memiliki sebuah orkestra Barat yang memainkan repertoar-repertoar standar Klasik Eropa. Saat itu Sultan mengundang Walter Spies untuk memimpin orkestra miliknya sebagai konduktor dan komposer. Selama menjabat sebagai dirigen Orkes Keraton Yogyakarta, Spies tinggal di nDalem Joyodipuran, ia juga menyempatkan belajar gamelan Jawa di Kadipaten Pakualaman (Rhodius, Darling, 1980: 21-27).

Pertumbuhan seni pertunjukan keraton sangat menonjol pada periode Sultan HB VIII (19211939). Khusus dalam iringan tari, gamelan disempurnakan, dan banyak gendhing-gendhing baru diciptakan untuk mengiringi tarian atau wayang wong. Sultan Hamengku Buwana VIII mendo- rong penuh para ahli seni dalam berkreasi sehingga banyak karya iringan tari menjadi lebih kaya dan lebih hidup, apalagi Sultan memiliki tokoh-tokoh yang ahli dalam bidang seni, seperti K.R.T. Wiroguno, K.R.T. Purbaningrat, K.R.T. Madukusumo, dan R.W. Larassumbogo, bahkan seni musik Barat dikembangkan pula untuk mengiringi beksan. Dua orang ahli musik Barat, yakni Spies dan Gotsch diminta melatih para musisi yang ada (Suharto, 1981: 119-121).

Sebuah penelitian tentang keberadaan Korps Musik Diatonik Keraton Yogyakarta oleh Tim Peneliti Akademi Musik Indonesia (AMI) tahun 1982 memberikan penjelasan bahwa kebutuhan upacara protokoler bukan hanya mencakup penggunaan kereta kebesaran raja yang bernama Kyai Garuda Yaksa dan beberapa perangkat lainnya, tetapi juga tentang adanya pembentukan suatu Korps Musik Barat yang dapat dikatakan representatif sebagai upacara penyambutan Gubernur Jenderal Belanda (Tim Peneliti AMI, 1982:14). Tim Peneliti AMI menyebutkan bahwa pertumbuhan fisik Korps Musik tersebut diawali dengan kehadiran Walter Spies pada awal tahun 1923, namun data ini tidak tepat jika dicocokkan dengan penulis biografi Spies, Hans Rhodius yang menulis bahwa kehadiran Spies di Yogyakarta dan mulai bergabung dengan Korps Musik Diatonik Keraton Yogyakarta tahun 1924 (Rhodius, Darling, 1980: 21).

\section{Walter Spies dan Musik di Yogyakarta}

Walter Spies adalah seniman multitalenta berkebangsaan Jerman, lahir di Moskow, Rusia pada tanggal 15 September 1895. Ayahnya bertugas sebagai seorang konsul di Jerman, ia belajar piano sejak usia muda dan mempunyai bakat besar pula dalam seni lukis dan drama. Pada saat terjadi Perang Dunia I (1914-1918), Spies diinternir oleh Rusia, yang waktu itu sedang perang melawan Jerman (Lindsay et al.: 1994, 125). Dalam interniran di pegunungan Ural, Spies banyak bergaul dengan suku Tartar yang membuatnya tertarik dengan musik tradisional suku tersebut. Setelah dibebaskan, ia kembali ke Jerman dan hidup sebagai seniman musik dan seni lukis. Merasa bosan 
hidup di Eropa, Spies memutuskan berlayar ke Timur, yaitu ke Hindia Belanda. Setibanya di Jawa, Spies pertama kali bermukim di Bandung pada awal 1923. Ia menjadi pianis di sebuah gedung bioskop Tionghoa sebagai ilustrator film "bisu" (Rhodius \& Darling, 1980: 9-11).

Pada akhir November 1923 Spies datang ke Yogyakarta untuk menemui seorang penyanyi bernama Maria Sitsen-Russer. Sitsen melihat kemampuan musikal Spies dalam bermain piano kemudian ia mendapat simpati dan kepercayaan untuk membuat sebuah konser bersama dengan hasil yang sangat memuaskan. Meskipun banyak mendapatkan tawaran untuk mengajar piano, Spies hanya bersedia mangajar anak-anak dari keluarga Sitsen (Rhodius \& Darling, 1980: 19-29); karena kepiawaiannya dalam bermain piano maka, lambat laun nama Walter Spies cepat populer di kalang-an pecinta musik di Yogyakarta, dan Carl Gotsch, seorang musisi dan sekaligus pimpinan orkes "Societeit de Vereeniging" menawarinya sebagai pianis di ensambelnya (Sidharta, 1999: 7).

Spies pertama kali masuk ke Keraton Yogyakarta ketika Sultan Hamengku Buwono VIII sedang mengadakan sebuah pesta besar, memperingati penobatan atas tahta keemasannya. Di dalam aula resepsi, suasana pesta nampak kontras, para pangeran dan puteri-puteri keraton duduk menge-lilingi aula mengenakan busana tradisional Jawa serba indah dan tampak ramping, bagaikan para bidadari, sementara para tamu dari orang-orang Eropa yang laki-laki mengenakan jas berekor ala Paris, dan yang wanita mengenakan gaun ala Eropa. Spies begitu terpesona mendengar alunan suara gamelan. Kekagumannya terhadap suara gamelan nampaknya menarik perhatian Sultan Hamengku Buwono VIII yang ingin mengetahui lebih banyak tentang tamunya yang baru dan masih muda ini (Rhodius \& Darling, 1980: 73).

Sejak peristiwa tersebut, selang beberapa hari Sultan mengutus K.R.T. Djojodipuro untuk menawari Spies pekerjaan sebagai pimpin-an orkestra Barat (Kapel Master) milik Sultan, dengan gaji 100 guilders per bulan. Meskipun ia bisa mendapatkan honor 1000 guilders per bulan dari bermain di societeit, ia lebih memilih pekerjaan barunya di Keraton Yogyakarta, maka secara resmi sejak tanggal 1 Januari 1924, Spies memegang pimpinan orkestra Barat milik Sultan (Rhodius \& Darling, 1980: 73). Selama tinggal di Yogyakarta, Spies menempati rumah K.R.T. Djojodipuro (Ndalem Djojodipuran), sedangkan para musisi Kraton Orcest Djogja tinggal di sebuah perkampungan yang disebut Kampung Musikanan (sebelah Timur Pagelaran Keraton Yogyakarta), dan di dalam keraton sendiri terdapat sebuah bangunan berbentuk seperti gazebo yang disebut Bangsal Mandalasana khususnya tempat untuk bermain instrumen musik Barat (Soekiman, 2000: 39).

Spies menjabat sebagai dirigen Kraton Orcest Djogja selama tiga tahun, (1924-1927). Dengan berat hati, Sultan Hamengku Buwono VIII mengabulkan permintaan Spies berhenti sebagai dirigen Kraton Orcest Djogja. Sebagai seniman yang multitalenta, sebelum berangkat ke Bali pada pertengahan tahun 1927, ia juga mendalami gamelan Jawa pada K.R.T. Djojodipuro dan di Pakualaman, kemudian setelah itu ia kemudian pindah ke Bali menjadi pelukis dan koreografer (Rhodius \& Darling, 1980: 21).

Selain bidang musik, termasuk melukis dan koreografi, Spies juga menciptakan "Tari Kecak” untuk kepentingan turis, seperti kita kenal sekarang. Beberapa lukisannya terjual dengan harga tinggi di berbagai lelang dunia, seperti Sotheby (London). Di Bali, Spies kemudian dikenal sebagai budayawan Bali Internasional, menjadikan tuan rumah bagi kaum elite Eropa dan Amerika yang berkunjung ke Bali (Sidharta, 1999: 8). Spies juga menjalin hubungan persahabatan dengan pasangan Gotsch (Carl-Olive), yang diwujudkan melalui surat-menyurat. Surat-surat itu meliputi kehidupan awal Spies di Bali sampai dengan sebelum penahanannya yang kedua dan terakhir oleh Belanda pada bulan Mei 1940. Untuk kedua kalinya setelah yang pertama di Rusia tahun 1915, ia ditahan karena keturunan Jerman. Tanggal 18 Januari 1942, kapal Van Imhoff yang membawa Spies beserta tawanan Jerman lainnya berangkat dari Padang menuju Ceylon, keesokan harinya pada saat kapal tersebut sudah mendekati Pulau Nias, kapal itu dibom oleh pesawat tentara Jepang yang mengira kapal itu adalah milik militer Belanda. Spies tak 
luput dari serangan ini, dan ia tewas dalam usia yang relatif masih muda pada empat puluh enam tahun (Rhodius \& Darling, 1980: 51).

Sepeninggal Spies, jabatan dirigen Kraton Orcest Djogja dipegang oleh Raden Lurah Regimentsdochter I. Pada tanggal 5 Agustus 1931, Raden Lurah Regimentdochter I wafat, kemudian sebagai pimpinan Kraton Orcest Djogja posisinya digantikan oleh Raden Lurah Regimentsdochter II (dikenal juga sebagai Raden Riyo Suryowaditra, pada tanggal 11 Januari 1950 mendapat anugerah kenaikan pangkat dengan sebutan Raden Wedono Prodjowaditra (Surtihadi, 2007: 29). Demikian sekilas kehidupan Spies, meski hanya tiga tahun bekerja sebagai Kapel Master di Keraton Yogyakarta, kontribusinya terhadap kehidupan musikal khususnya musik Barat di keraton sangat besar. Terbukti beberapa manuskrip Spies masih tersimpan dengan baik di Keraton Yogyakarta berupa notasi gamelan ke dalam bentuk musik untuk piano (Lindsay et al., 1994: 60-61).

Berikut beberapa contoh nama Gendhing Gati yang dipakai untuk mengiringi Kapangkapang Bedhaya dan Srimpi: (1) Gendhing Gati Brongto, (2) Gendhing Gati Raja, (3) Gendhing Gati Mardawa, (4) Gendhing Gati Padasih, (5) Gendhing Gati Wiwaha, (6) Gendhing Gati Sangaskara (Soerjadiningrat, 1980: 35-39). Gendhing-gendhing iringan beksan Lawung Ageng pada dasarnya ada tiga gendhing inti, yakni (1) Gendhing Gangsaran, (2) Gendhing Roning Tawang, (3) Gendhing Rog-rog Asem, kemudian kembali ke Gendhing Gangsaran. Dalam urutan dari depan gendhing Lawung Ageng untuk mengiringi penari Lawung Jajar: Gangsaran-Roning Tawang-Gangsaran; sedangkan urutan untuk mengiringi penari Lawung Lurah: Bima Kurda-Roning Tawang-Gangsaran.

Dalam membaca notasi gendhing yang telah ditranskrip ke dalam notasi balok (khususnya dalam iringan kapang-kapang), para musisi harus dapat memahami urutan frase kalimat gendhing yang diakhiri dengan bunyi instrumen gong besar. Hal ini menyebabkan berhentinya musik tidak selalu di bagian akhir kalimat musiknya, berhentinya musik dapat terjadi di tengah atau bahkan di bagian depan frase kalimat musik yang selalu diakhiri dengan bunyi gong besar. Dalam mengiringi tari bedhaya ataupun srimpi harus menyesuaikan dengan durasi bagian kapang-kapang yang selalu berbeda-beda. Besar-kecilnya pendapa empat menari yang dipakai untuk pentas sangat memengaruhi durasi musik yang mengiringi.

Notasi pada gambar 3 adalah cuplikan notasi gendhing yang sudah ditranskrip ke dalam notasi balok untuk mengiringi beksan Lawung Ageng sesuai dengan urutan.

KETERANGAN

\section{Lawung Ageng}

\section{Tanda adalah Gong Besar}

-

GANGSARAN

(5 X ulang)

Orchestra Play

Buka kendang

Balungan
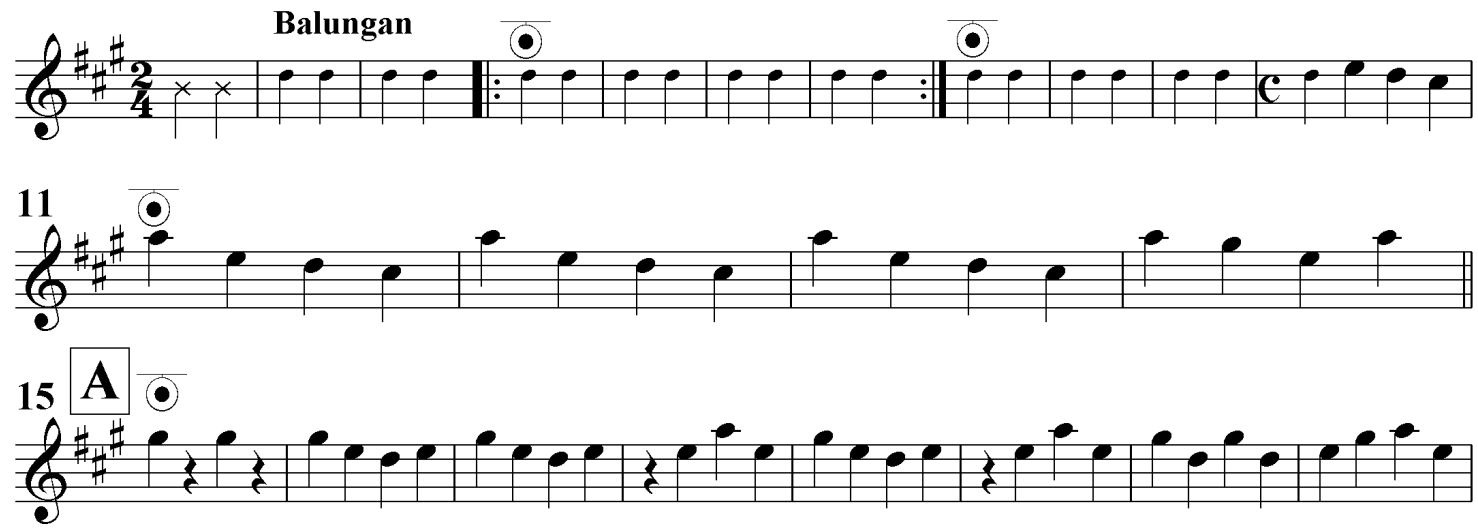

Gambar 3. Notasi balok gendhing Gangsaran. 


\section{GATI WIWAHA}

BUKA BONANG

Cello \& B Bass

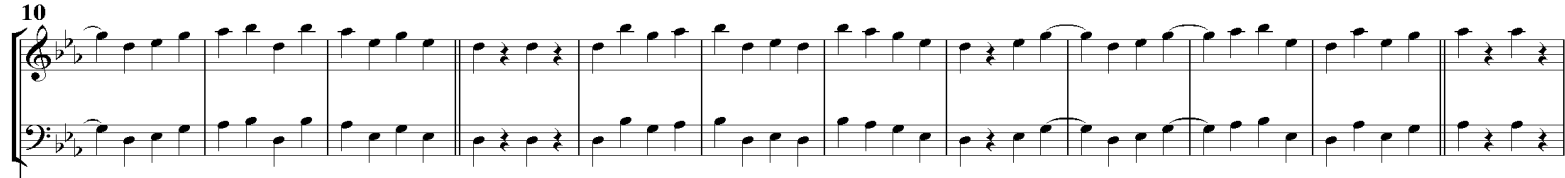

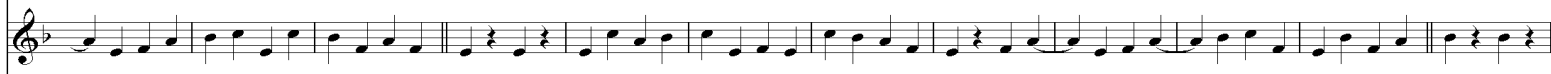

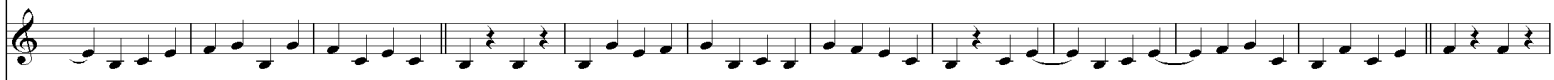

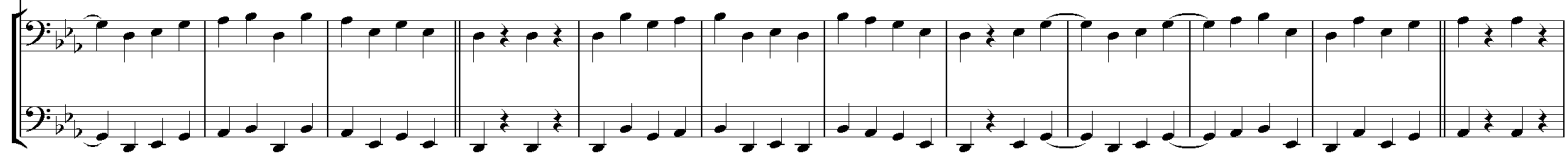

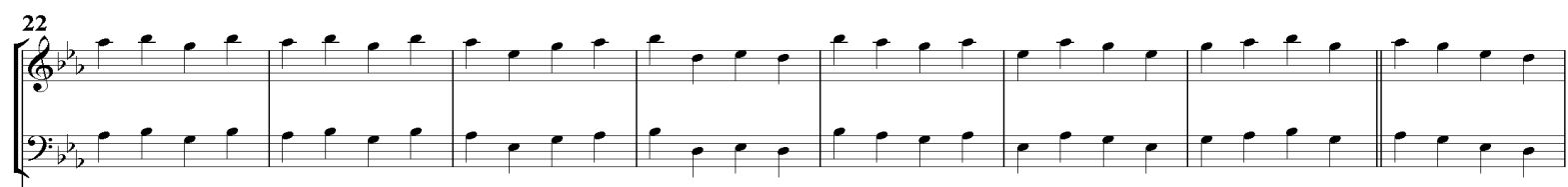

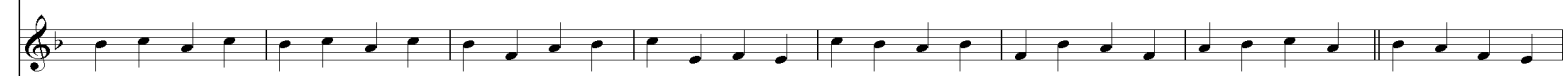

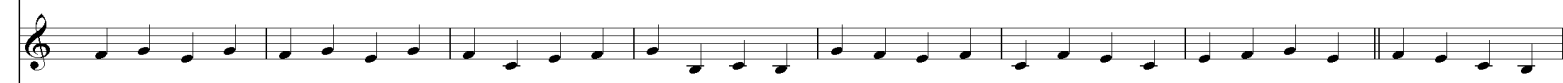

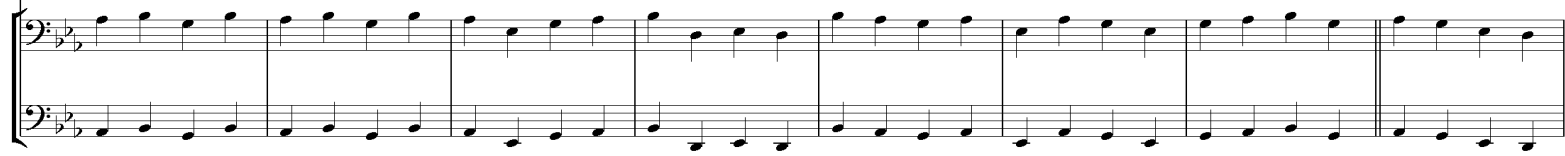

$\left[\begin{array}{lllll|l}30 & \ldots & \ldots & \ldots \\ \hline\end{array}\right.$

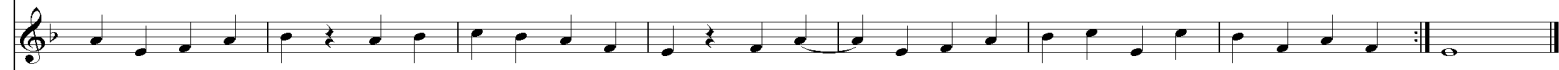

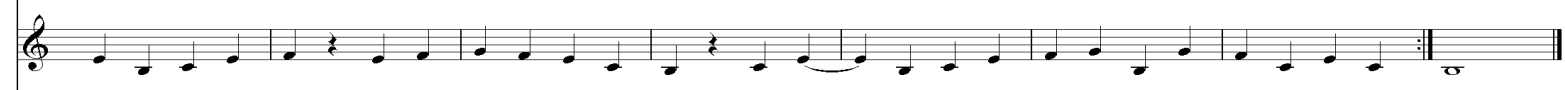

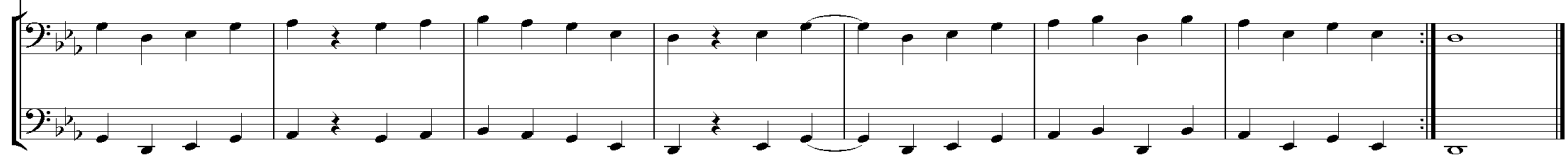

Gambar 4. Notasi balok gendhing Gati Wiwaha untuk mengiringi tari. 


\section{GATI SANGASKARA}

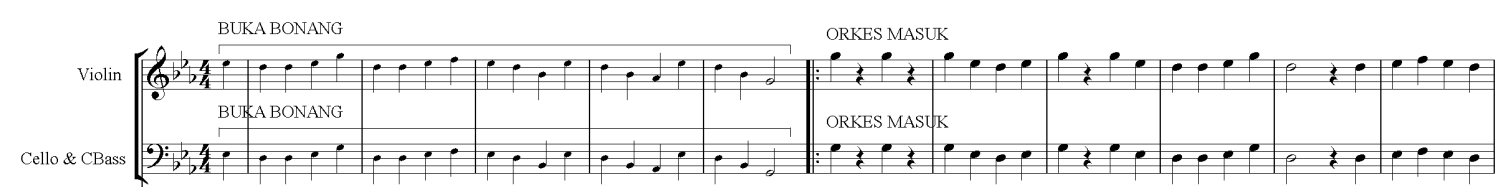

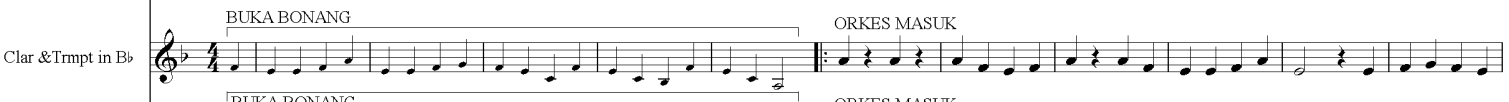
Alto Saxophone

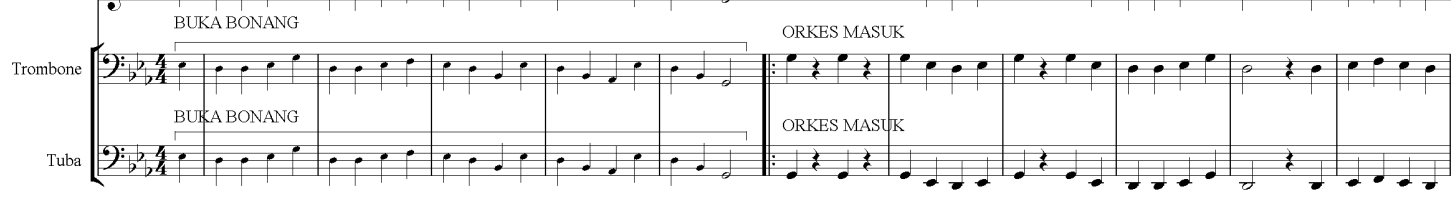

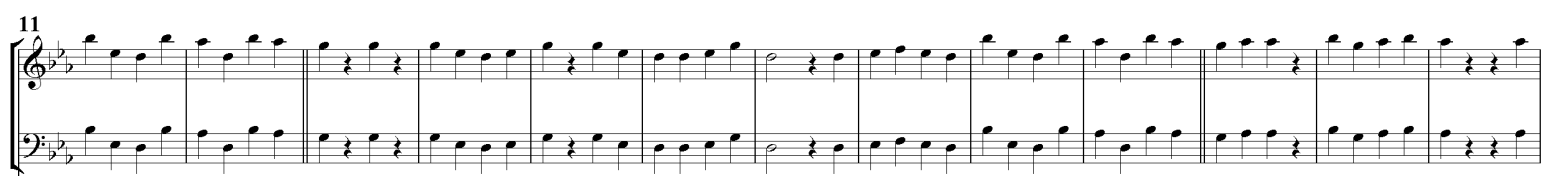

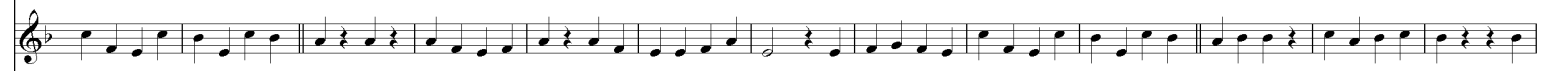
$\ell_{0} \ldots \ldots \ldots$

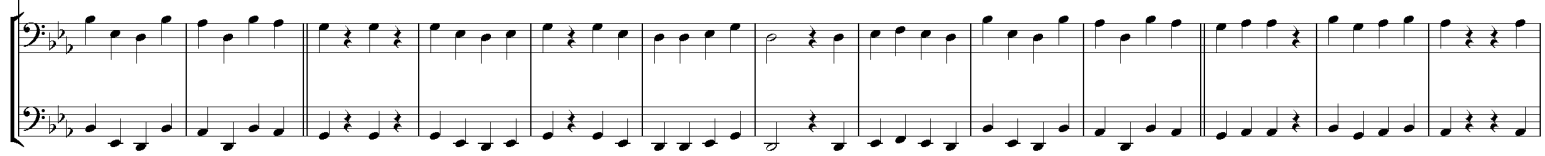

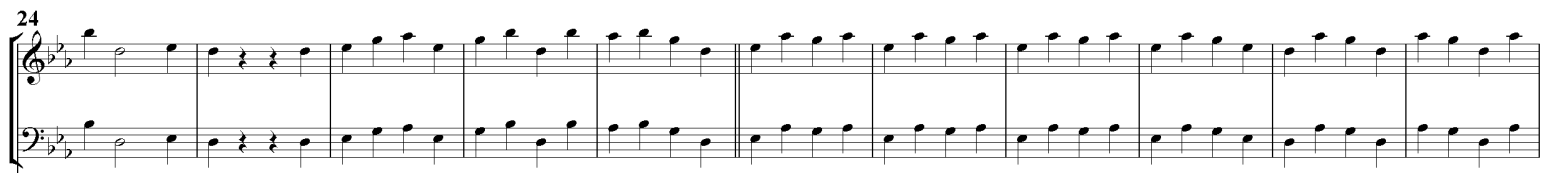

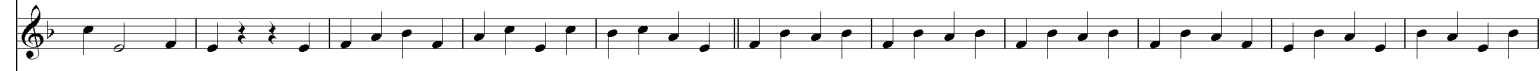

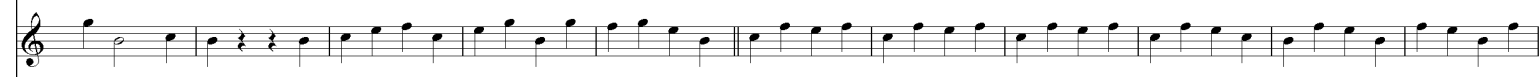

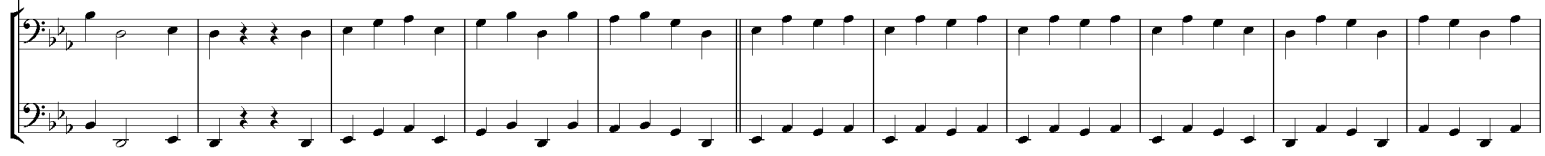

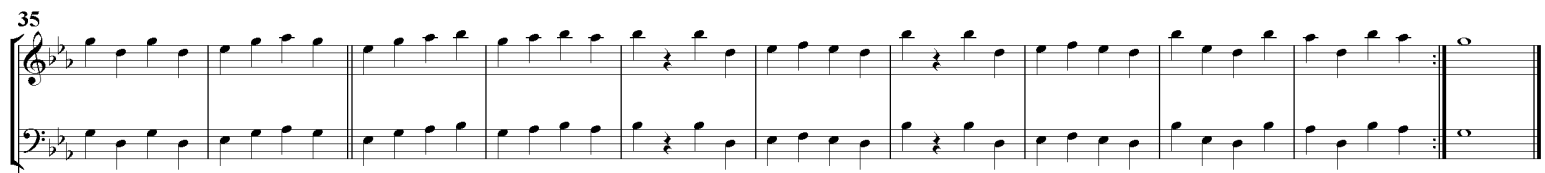

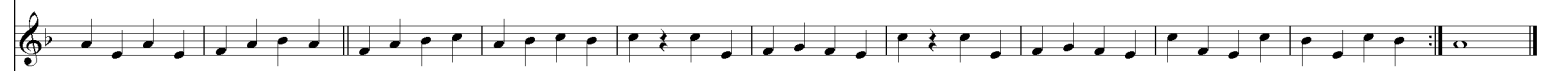

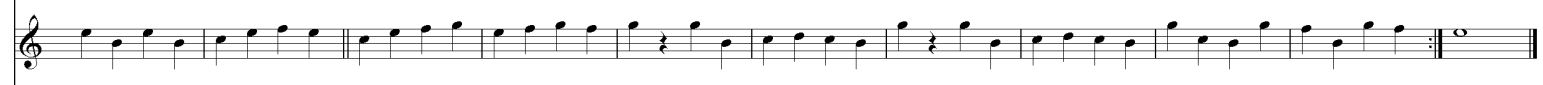

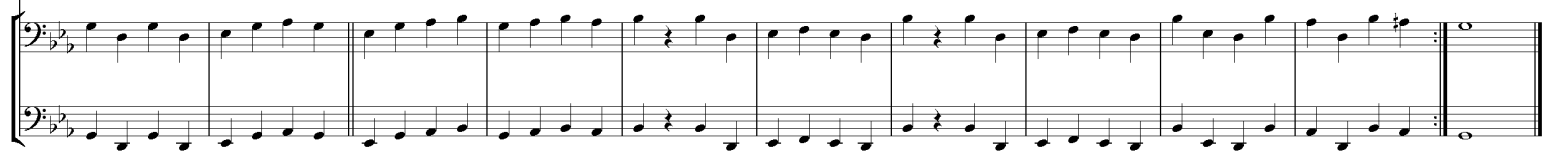
Gambar 5. Fullscore gendhing Gati Sangaskara untuk mengiringi Kapang-kapang mundur. 
Semua notasi untuk orkestra disesuaikan dengan gamelan, yaitu dimainkan satu suara (unisono). Transkripsi ini tidak menunjukkan adanya aransemen baru sehingga tidak ada suara lain kecuali melodi pokok. Kesulitan yang dihadapi dalam mengerjakan transkrip ini adalah pada penyamaan tune-nya. Sebelum masuk gendhing Gangsaran untuk gerakan sodoran/adu tombak selalu disisipi dengan gendhing transisi yang disebut gendhing Rog-rog Asem seperti pada gambar 6.

Dalam beksan Lawung Ageng ini terdapat dua kali adegan/gerakan sodoran, yang pertama dilakukan oleh penari Lawung Jajar dengan gendhing Gangsaran. Namun, setiap pada bagian sodoran ini instrumen musik tidak ikut bermain.
Setelah sodoran selesai dilakukan, gendhing Roning Tawang dimainkan kembali.

Setelah sodoran yang dilakukan oleh penari Lawung Jajar selesai, kembali ke gendhing Roning Tawang dan kemudian ada empat penari Lawung Lurah masuk ke atas pentas dengan diiringi gendhing Bima Kurda setelah posisi mereka berada di tengah-tengah pendhapa.

Selama penari Lawung Lurah menari hingga sebelum gerakan sodoran, mereka diiringi gendhing Bima Kurda. Selanjutnya, beberapa gerakan sebelum sodoran diiringi gendhing Rog-rog Asem. Pada gerakan sodoran diiringi gendhing Gangsaran.Setelah gerakan sodoran kembali lagi diiringi gendhing Bima Kurda dan diakhiri dengan gendhing Gangsaran.
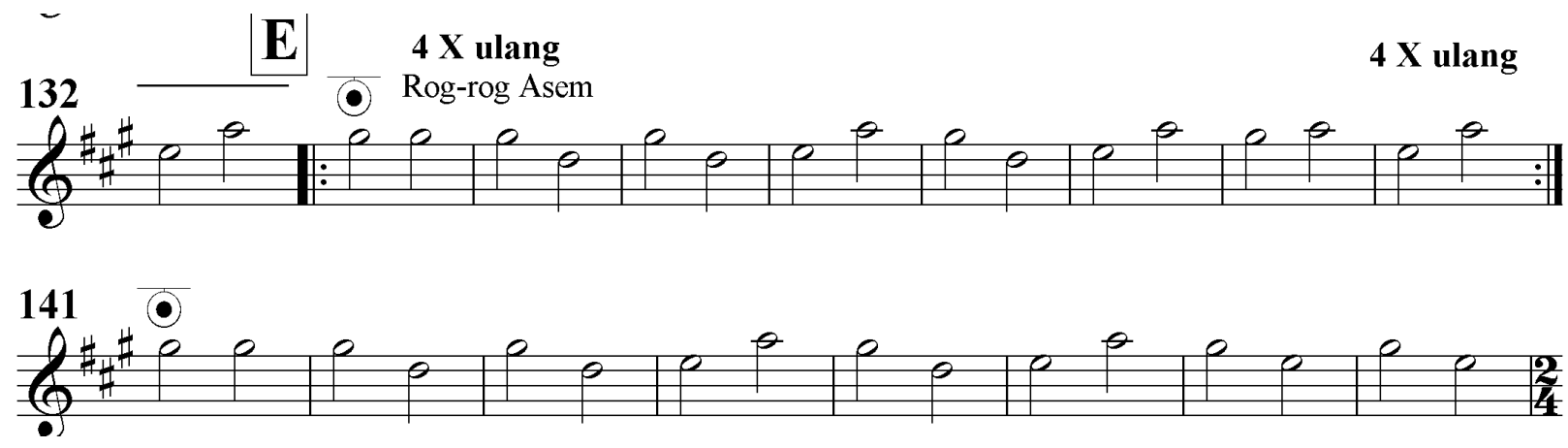

Gambar 6. Notasi balok gendhing Rog-rog Asem.

\section{BIMA KURDA}
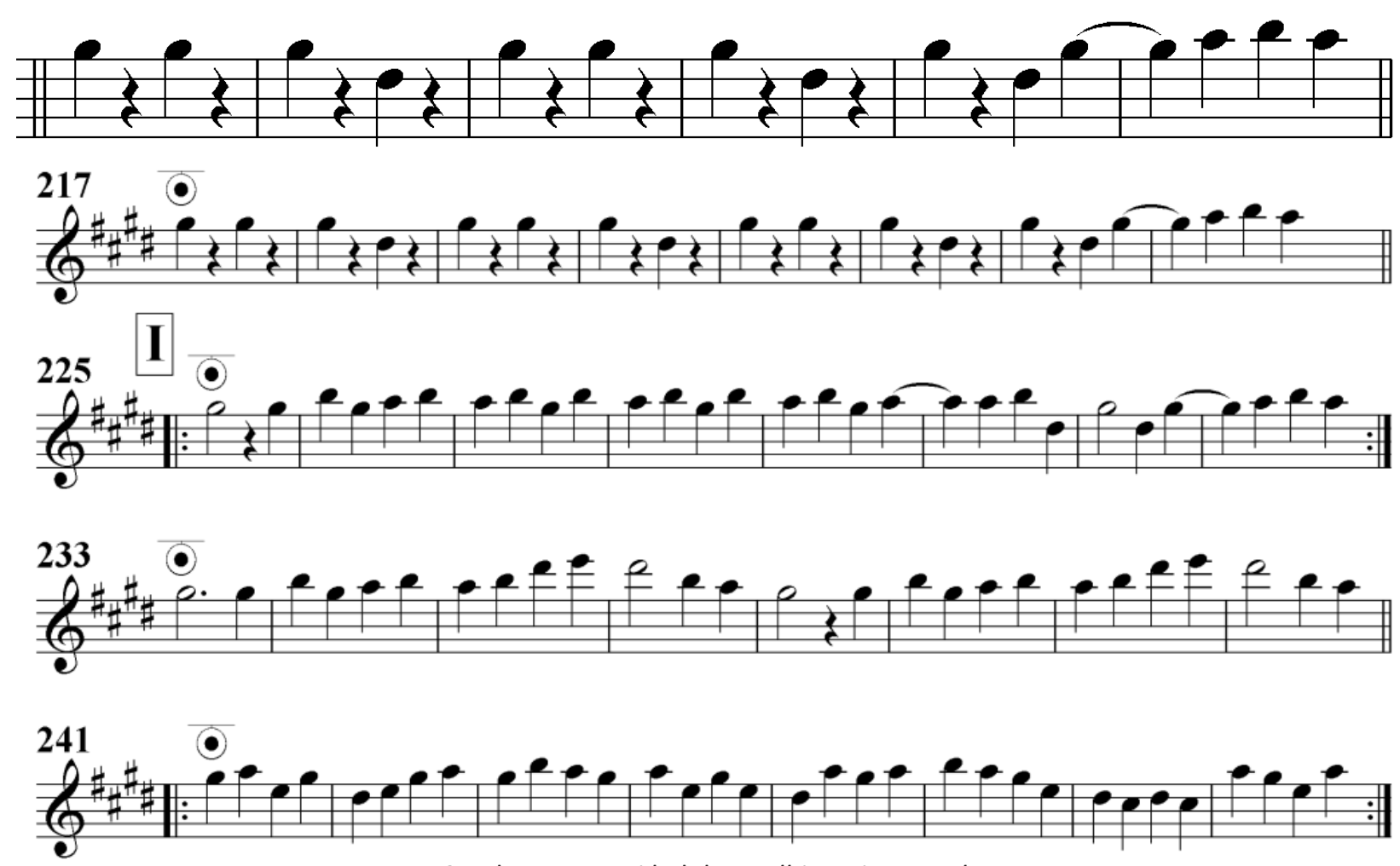

Gambar 7. Notasi balok gendhing Bima Kurda. 


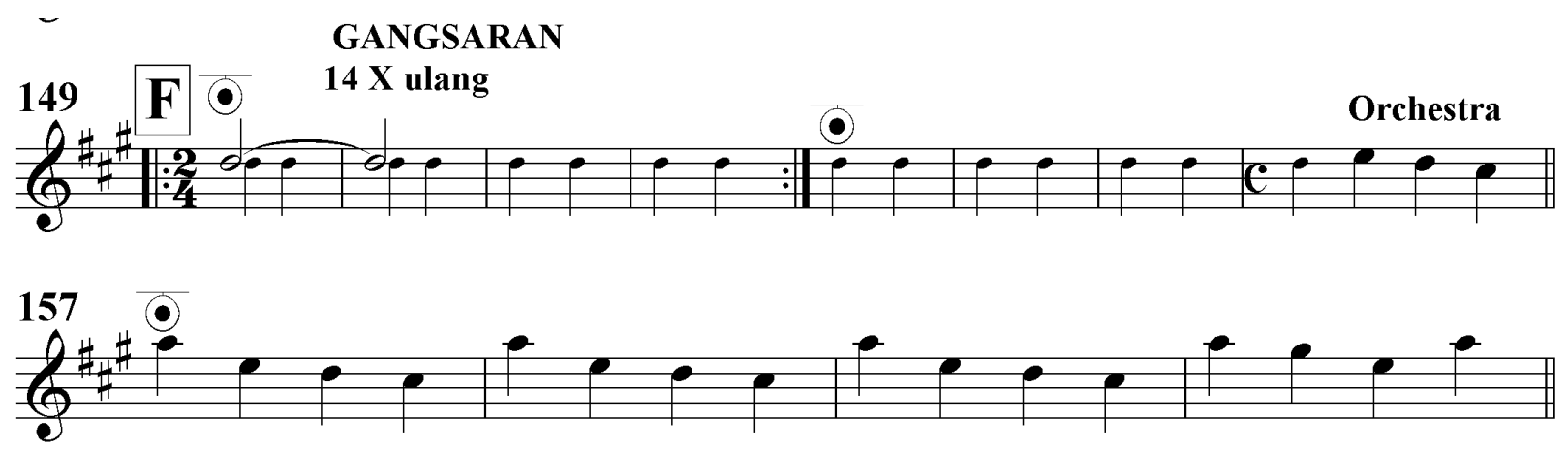

Gambar 8. Notasi balok gendhing Roning Tawang.
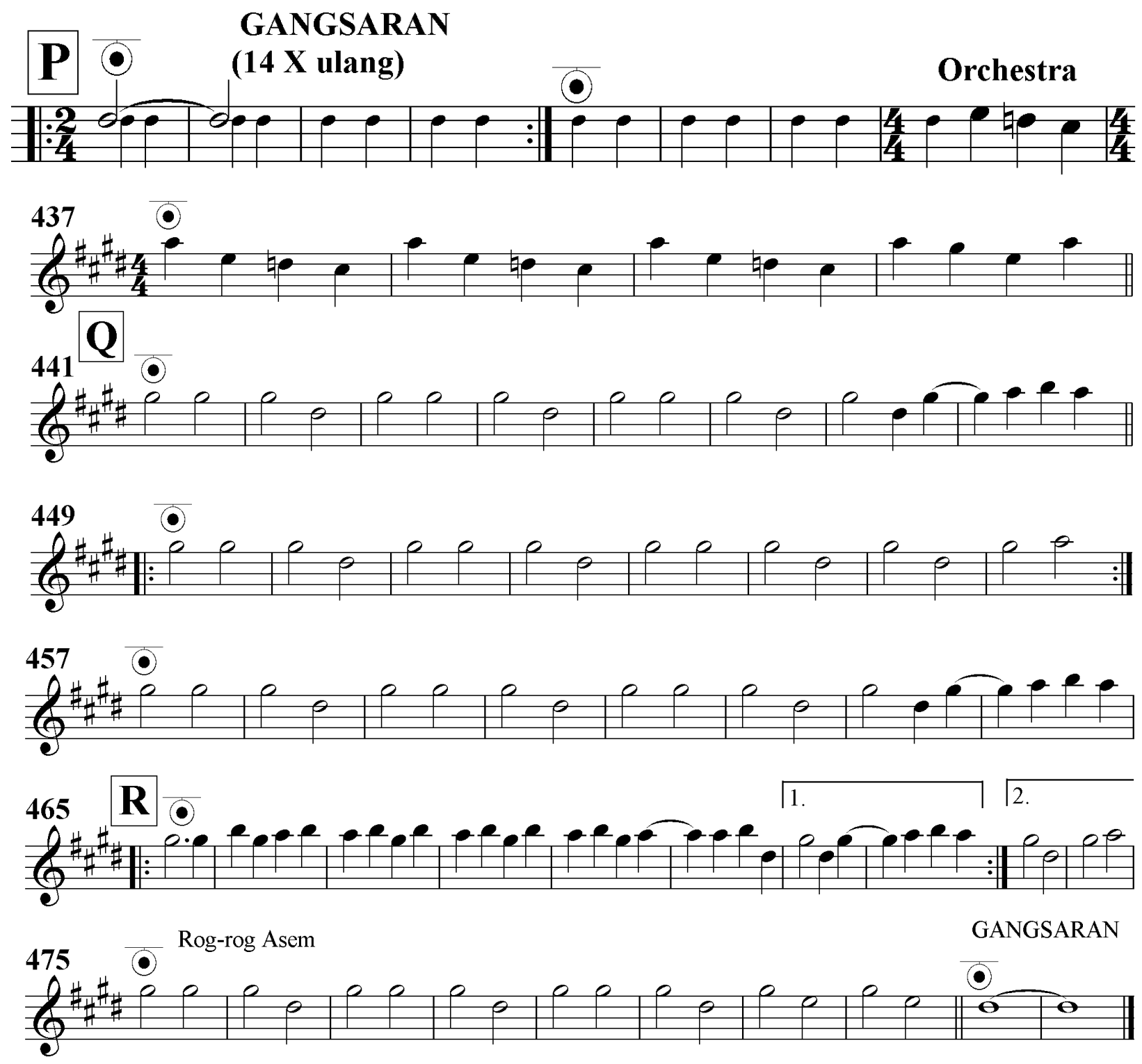

Gambar 8. Notasi balok gendhing Gangsaran dan gendhing Rog-Rog Asem.

Simpulan

Kehadiran instrumen musik Barat di Yogyakarta sejak masa pemerintahan Sultan Hamengku Buwana I (1755-1792) dimulai dengan adanya sumbangan instrumen terompet dari
Belanda untuk melengkapi kebutuhan protokoler keraton. Keberadaan instrumen musik Barat terus berlanjut pada masa Sultan Hamengku Buwana II (1792-1810) dengan adanya jabatan abdi dalem tambur suling salompret. Terminologi ini mengacu pada pemain terompet. Perpaduan instrumen 
musik Barat (terompet dan tambur) dengan gamelan Jawa dilakukan masa Sultan Hamengku Buwana V (1823-1855) untuk mengiringi beksan Kapang-kapang Srimpi dan Bedhaya, serta untuk mengiringi beksan Lawung Ageng, yang mengerjakan perpaduan kedua jenis instrumen itu adalah dua orang Belanda bernama Van Gought dan Smith atas perintah Sultan Hamengku Buwana V (1823-1855). Perpaduan instrumen musik Barat dengan gamelan Jawa mencapai puncaknya pada masa Sultan Hamengku Buwana VIII (1921-1939); manakala Sultan mempunyai sebuah Korps musik diatonik Barat yang dikenal dengan nama Kraton Orcest Djogja dengan dirigen Walter Spies (19241927). Sepeninggal Spies, jabatan dirigen Kraton Orcest Djogja digantikan oleh musisi lokal. Orkestra Barat milik sultan ini diketahui mampu memainkan berbagai jenis musik seperti musik Klasik, Waltz, Polonais, dan Jazz. Iringan kapang-kapang Bedhaya dan Srimpi ataupun beksan Lawung Ageng diiringi orkestra lengkap yang meliputi instrumen gesek, instrumen tiup kayu, instrumen tiup logam, dan instrumen perkusi berupa genderang serta tambur.

Suatu keunikan bahwa Keraton Yogyakarta sebagai pusat budaya Jawa yang sarat akan upacaraupacara tradisi Jawa, namun budaya Barat (musik Barat) mampu menjadi bagian dari tradisi seni pertunjukan di keraton. Perkembangan orkestra musik Barat di Keraton Yogyakarta ataupun penggunaan instrumen musik Barat secara lengkap yang dipadukan untuk iringan tarian keraton mempunyai asumsi bahwa hal tersebut merupakan bagian dari "politik kebudayaan" Sultan Hamengku Buwana VIII yang ingin menunjukkan kebesarannya melalui kemegahan budaya.

\section{Ucapan Terima Kasih}

Pada kesempatan ini penulis ingin menyampaikan ucapan terima kasih dan penghargaan sangat tinggi kepada: (1) G.B.P.H. H. Prabukusumo, S.Psi. selaku Pèngagèng Kawedanan Hangeng Punakawan Widya Budaya yang telah memberikan izin, fasilitas, dan kemudahan penulis melakukan studi pustaka di Keraton Yogyakarta, (2) Drs. G.B.P.H. H. Yudaningrat, M.M. selaku Pèngagèng Kawedanan Hageng Punakawan Krida Mardawa yang telah memberikan izin, kesempatan, fasilitas, dan kemudahan penulis melakukan studi pustaka di Keraton Yogyakarta, (3) K.R.T. Purwodiningrat (81 tahun) selaku narasumber dan sebagai $A b d i$ Dalem réh Kawedanan Hageng Punakawan Widya Budaya Keraton Yogyakarta, (4) Agus Susanto $(59$ tahun) Abdi Dalem Ungel-ungelan (Korps Musik) Prajurit Keraton Yogyakarta (salah seorang keturunan Abdi Dalem Musikan masa pemerintahan Sultan HB VIII (1921-1939) yang telah memberikan informasi berharga tentang aktivitas Korps Musik Diatonik Keraton Yogyakarta masa lalu, dan (5) Kepala Perpustakaan Museum Negeri Sana Budaya Yogyakarta, atas segala fasilitas yang diberikan kepada penulis selama melakukan studi pustaka.

\section{Kepustakaan}

Babad Ngayogyakarta. Vol. III. Yogyakarta: Perpustakaan Museum Sana Budaya Yogyakarta.

Carey, Peter and Hoadley. 2000. "The Archive of Yogyakarta”. Vol. II, Mason C. (ed.). Documents Relating to Economic and Agrarian Affairs. London: Oxford University Press.

Kartahasmara, R.Ng. 1990. Ngayugyakarta Pagelaran. Transliterasi Wibatsu Harianto Soembogo. Yogyakarta: Mahadewa.

Kartodirdjo, Sartono. 1993. Pendekatan Ilmu Sosial Dalam Metodologi Sejarah. Jakarta: Gramedia Pustaka Utama.

Kunst, Jaap. 1973. Music in Java: Its History, Its Theory and Its Technique. The Hague: Martinus Nijhoff.

Lindsay, Jennifer et al. 1994. Katalog Induk Naskahnaskah Nusantara Jilid 2: Keraton Yogyakarta. Jakarta: Yayasan Obor Indonesia.

Mardowo, RB Pustaka. 1981. "Iringan dan Perlengkapan” dalam Fred Wibowo (ed.). Mengenal Tari Klasik Gaya Yogyakarta. Yogyakarta: Dewan Kesenian.

Rhodius, Hans \& John Darling. 1980. Walter Spies and Balinese Art. Amsterdam: Terra, Zutphen.

Ricklefs, M.C. 1974. Jogjakarta Under Sultan Mangkubumi (1749-1792), A History of The Division of Java. London: Oxford University Press. 
Soedarsono, R.M. 1989. "Raja Jawa dan Seni: Sebuah Contoh Pengaruh Konsepsi Seni Pertunjukan”. Makalah Ceramah pada Proyek Penelitian dan Pengkajian Kebudayaan Nusantara, Bagian Jawa, tanggal 25 September 1989.

. 2010. Seni Pertunjukan

Indonesia di Era Globalisasi. Yogyakarta: Gadjah Mada University Press.

Surtihadi, R.M. 1995. "Instrumen Musik Tradisi Barat Dalam Iringan Tari dan Upacara Protokoler Kraton Yogyakarta (Sebuah Tinjauan Historis)”. [Skripsi]. Yogyakarta: Fakultas Seni Pertunjukan ISI Yogyakarta. 2007. "Musik Orkestra Barat di

Yogyakarta Masa Pra Kemerdekaan" dalam Resital, Jurnal Seni Pertunjukan. Volume 8 No.1Juni 2007: 27-38.

Sidharta, Amir. 1999. "Kabar dari Bali: Surat-Surat

Spies kepada Pasangan Gotsch", MITRA:

Jurnal Budaya dan Filsafat No. 3 - Desember.

Soekiman, Djoko. 2000. Kebudayaan Indis dan

Gaya Hidup Masyarakat Pendukungnya di Jawa (Abad

XVIII - Medio Abad XX) Yogyakarta: Bentang
Budaya.

Soerjodiningrat, Wasisto. 1980. Gendhing Beksan Mataraman. Yogyakarta: Proyek Peningkatan Pengembangan Perguruan Tinggi.

Suharto, Ben. 1981. "Perkembangan Tari Klasik Gaya Yogyakarta" dalam Fred Wibowo (ed.). Mengenal Tari Klasik Gaya Yogyakarta. Yogyakarta: Dewan Kesenian.

Sumarsam. 2003. Gamelan, Interaksi Budaya dan Perkembangan Musikal di Jawa. Yogyakarta: Pustaka Pelajar.

Tim Peneliti Akademi Musik Indonesia. 1982. "Laporan Penelitian Musik Diatonik Kraton Kasultanan Yogyakarta”. Yogyakarta: AMI.

\section{Informan}

K.R.T. Purwodiningrat (81 tahun). Abdi Dalem Reh Kawedanan Hageng Punakawan Widya Budaya Keraton Yogyakarta, tinggal di Kadipaten Kidul 44 Yogyakarta.

Agus Susanto (59 tahun). Abdi Dalem UngelUngelan (Korps Musik) Prajurit Keraton Yogyakarta, tinggal di Musikanan PB I/87 Yogyakarta. 